\title{
Immunohistochemical examination on the effects of malathion and Onosma nigricaule (Boraginaceae) on the catalase (CAT) and superoxide dismutase-2 (Mn-SOD) in renal tissues of mice*
}

\author{
Buket BAKIR ${ }^{1}$, Dinçer ERDAĞ ${ }^{2}$, Sevda ELİ̧̧ YILDIZ ${ }^{3}$, Ebru KARADAĞ SARI ${ }^{4}$, Hasan ASKER $^{5}$, \\ Mahmut SÖZMEN'
}

\begin{abstract}
${ }^{1}$ Namık Kemal University, Faculty of Veterinary Medicine, Department of Histology and Embryology, Tekirdağ ${ }^{2}$ Kafkas University, Health Services Vocational School; ${ }^{3}$ School of Health Sciences; ${ }^{4,5}$ Faculty of Veterinary Medicine, Department of Histology and Embryology, Kars; ${ }^{6}$ Ondokuz Mayıs University, Faculty of Veterinary Medicine, Department of Pathology, Samsun, Turkey.
\end{abstract}

\begin{abstract}
Summary: The purpose of this study was to determine the effects of the plant extract, which is obtained from Onosma nigricaule due to the oxidation parameters caused in mice by malathion that is used as an insecticide in agriculture, on catalase (CAT) and superoxide dismutase-2 (Mn-SOD) in kidney tissues by immunohistochemical technique. A total of 48 male mice (Mus musculus) were used in our study. Mice were divided 6 groups (control group, maize oil group, normal saline group, Onosma nigricaule group, malathion group, Onosma nigrcaule+malathion group). Hematoxylin-eosin and triple staining methods were used for histological and pathological examinations. The localization of CAT and Mn-SOD in the renal tissue was determined using the method of streptavidinbiotin-peroxidase. CAT immunoreactivity was determined with a weak intensity in epithelium of renal tubulus proximalis of mice in the malathion group, with a moderate intensity in Onosma nigricaule+malathion group and with a higher intensity in tubulus proximalis of other groups. A cytoplasmic Mn-SOD immunoreactivity was determined with weak intensity in renal medulla of mice in malathion group, with moderate intensity in renal medulla of mice in Onosma nigricaule plant extract+malathion group, maize oil group, and normal saline group and with highly intensity in control and Onosma nigricaule groups. It was concluded that Onosma nigricaule might play a protective role as an antioxidant against the oxidant features of malathion.
\end{abstract}

Keywords: Catalase, kidney, malathion, mice, Onosma nigricaule, superoxide dismutase.

\section{Malathion ve Onosma nigricaule (Boraginaceae)'nin fare böbrek dokusunda katalaz (CAT) ve süperoksit dismutaz-2 (Mn-SOD) salınımı üzerine etkileri}

Özet: Bu çalışmada, tarımda insektisit olarak kullanılan ve farelerde oksidasyon parametrelerine neden olan malathiona karşı Onosma nigricaule'den elde edilen bitki ekstraktlarının immunohistokimyasal yöntemle böbrek dokusunda katalaz (CAT) ve süperoksit dismutaz-2 (Mn-SOD) salınımı üzerine etkilerinin saptanması amaçlanmıştır. Çalışmamızda 48 adet erkek (Mus musculus) fare kullanıldı. Fareler 6 gruba (kontrol grubu, mısır yağı grubu, serum fizyolojik grup, Onosma nigricaule grubu, malathion grubu, Onosma nigricaule + malathion grubu) ayrıld. Histolojik ve patolojik değerlendirmeler için hematoksilen-eozin and triple boyama yöntemleri kullanıldı. Böbrek dokusunda CAT ve Mn-SOD lokalizasyonu için ise streptavidin-biotin- peroxidase yöntemi kullanıldı. CAT immunoreaktivitesinin fare böbrek dokusunun tubulus proksimalisinde olduğu görüldü. CAT immunoreaktivitesinin malathion grubunda zayıf, malathion+Onosma nigricaule grubunda orta yoğunlukta, diğer gruplarda ise yüksek yoğunlukta olduğu tespit edildi. Mn-SOD immunoreaktivitesinin böbrek medullasında olduğu görüldü. Malathion grubunda zayıf, mısır yağı grubu, serum fizyolojik ve Onosma nigricaule+malathion gruplarında orta yoğunlukta, kontrol ve Onosma nigricaule gruplarında ise yüksek yoğunlukta olduğu tespit edildi. Onosma nigricaule'nin malathionun oksidadif etkilerine karşı antioksidan gibi koruyucu bir rol oynadığı sonucuna varılabilir.

Anahtar sözcükler: Böbrek, fare, katalaz, malathion, Onosma nigricaule, süperoksit dismutaz.

\section{Introduction}

Pesticides, which are used for destroying the harmful insects, having a more comfortable life and quality products, might eradicate not only the target organisms, but also the off-target living creatures (19).
Malathion, were presented for the first time in 1937 and considered as a chemical weapon in the beginning. Such pesticides are able to show the effects, which are showed in nervous system of insects, in living creatures with high organization in a similar way. These substances

\footnotetext{
* This research was supported by a grant from the Kafkas University, BAP (Project No: 2013-KSYO-78.
} 
affect not only the off-target organisms in various ways, but also the nervous system, endocrine system, immune system, as well as the liver, muscular, cardiac, urinary, and other systems in the organism $(1,3,11,16,23,29)$.

Being one of the enzymatic antioxidants, the catalase (CAT) is a hem-enzyme weighing $60 \mathrm{kDa}$ and involving four tetrahedral subunits with the same structure. Having a molecular weight of $240 \mathrm{kDa}$, it involves four ferriprotoporphyrins in each molecule. Catalase catalyzes the reaction, which disintegrates the hydrogen peroxide into oxygen and water (18). CAT is available in various tissues of the living organism such as erythrocyte, liver, kidney and bone marrow (24).

Superoxide dismutase (SOD) catalyzes transformation of the superoxide into hydrogen peroxide and molecular oxygen (8). Four types of SOD were identified; copper and zinc-containing dismutase $(\mathrm{Cu} / \mathrm{Zn}$ SOD, SOD-1), manganese-containing dismutase (Mn-SOD, SOD-2), extracellular dismutase (Ec-SOD, SOD-3) and nickelcontaining dismutase (Ni-SOD, SOD-4) (18). Manganese dismutase has a homotetramer structure and contains a manganese atom for each subunit. It has a molecular weight of $96 \mathrm{kDa}$ and is reported to be the antioxidant enzyme with the strongest anti-tumor effect (28).

Being an endemic species for Turkey, Onosma nigricaule is a plant of the Boraginaceae family, which usually grows in tropical and temperate regions. This plant is also used in the treatment of diseases such as eye diseases, blood disorders, bronchitis, stomachache, and against disturbances such as inflammation, rash, fever, scar, hemorrhoid and kidney stone (26).

This study intended to examine the effect of Onosma nigricaule, which is reported to be protective and therapeutic $(4,26)$, on the changes caused by malathion that is among organophosphorus pesticides, in the renal tissue and immunohistochemical oscillation of CAT and Mn-SOD that are among antioxidant enzymes. The discovery of antioxidant features of Onosma nigricaule against the oxidant features of malathion, presence of the protective effects of this plant against pharmacological effects and possible damages of pesticides, and the opinion that it would lead new alternative ways in the field of medicine and pharmaceutical industry form the basis of this study.

\section{Materials and Methods}

Plant material: The plant of Onosma nigricaule (Boraginaceae) was collected and dried in the province of Kars between May-September. Following the process of drying, the leaves of the plant were ground by means of a mill until they were crushed into powder. The extracts were taken from plants with the soxhlet system. The plant powder was used as $25 \mathrm{gr}$ for each experiment. This extract substance was dissolved in the physiological saline and then injected to experimental animals intraperitoneally for antioxidant tests. The study of Erdag (2012) was taken into consideration to determine on which doses the plant extract and plant sub-species had an antioxidant effect.

Animal material: Approval of the Animal Experiments Local Ethics Committee of Kafkas University (Decree no: 26.11.2010/48) for the study was taken. A total of 48 male mice of the same species (Mus musculus), which were in the puberty age, 7-8 weeks old, weighted approximately 22-35 g, had not mated and been used in any other studies before, were used in the study. The animals were kept in standard cages at ambient temperature of $22 \pm 2^{\circ} \mathrm{C}$ for 12 hours in light and 12 hours in dark environment, and fed with normal rat feed and tap water as ad libitum.

Experimental groups were formed in such a way to involve 8 male mice in each group. The chemical substances and extracts to be given to animals were dissolved as 100 $\mathrm{mg} / 10 \mathrm{ml}$ in appropriate solutions (malathion was dissolved in maize oil and extracts were dissolved in physiological saline). As a consequence, $0,2 \mathrm{ml} / 20 \mathrm{~g}$ of solution, water or maize oil, was intraperitonally (i.p.) injected to other groups except for the negative control group for 21 days.

6 separate groups were formed for the experiment.

1. Control group mice were designed as the negative group and no substance application was performed.

2. Malathion group mice were applied with maize oil, which is the transport substance of malathion.

3. Normal saline group mice were daily applied with normal saline $(0.9 \% \mathrm{NaCl})$, which is the transport substance of the plant extract.

4. Onosma nigricaule group mice were daily applied with the plant extract of Onosma nigricaule (Boraginaceae), which was dissolved in normal saline.

5. Maize oil group mice were daily applied with malathion, which was dissolved in maize oil.

6. Onosma nigricaule+malathion group mice were daily applied with the plant extract of Onosma nigricaule (Boraginaceae)+malathion.

At the end of the $21^{\text {st }}$ day, mice were weighed and then euthanized under the ether anesthesia to take renal tissue samples.

Histopathological procedure: For light microscopic examinations, the left kidney was fixed in phosphatebuffered $10 \%$ formalin, processed and embedded in paraffin, then cut into $5-\mu \mathrm{m}$ sections using conventional techniques. Sections were stained with hematoxylin-eosin (HE) and triple (17). Whole colored slides, containing at least 50 glomeruli each, were analyzed. 
Immunohistochemical examination: The slides that were coated with chrome alum gelatin and $5 \mu \mathrm{m}$ thick cross-sections that were extracted from paraffin blocks were applied with the Streptavidin-biotin peroxidase technique, which is one of the indirect methods (27). Following the deparaffinization and rehydration processes, the cross-sections were shaken within PBS $(0.1$ $\mathrm{M}, \mathrm{pH}, 7.2$ ) and incubated for 15 minutes in $\mathrm{H}_{2} \mathrm{O}_{2}$ of $3 \%$ that was prepared in PBS of $0.1 \mathrm{M}$ to prevent the endogenous peroxidase activity. After being washed with PBS, they were heat-treated within citrate buffer solution at maximum temperature in microwave oven for 10 minutes in order to reveal the antigens. Then, they were washed with PBS once again. Cross-sections were applied with primary antibodies of CAT (Abcam, Cambridge MA, USA, diluted at a rate of 1/1000) and Mn-SOD (Santa Cruz, B-1: sc-133254, diluted at a rate of 1/500) in humid environment at room temperature for 1 hour. Only PBS was dripped on the tissues of the negative control group. Streptavidin-HRP (Horse Radish Peroxidase) (Invitrogen Histostain plus Broad Spectrum Ref. 85.9943) was dripped on the sections, and then incubated at room temperature for 15 minutes. 3,3'-diaminobenzidine tetrahydrochloride $(0.5 \mathrm{mg} / \mathrm{mL}$; Dako Corp. $)$ was used as chromogen followed by hematoxylin counterstaining. The preparates were analyzed in the research microscope (Olympus BX51, Shinjuku, Tokyo Japan) and their photos were taken. CAT and Mn-SOD immunoreactivities in cells were determined with the semiquantitative method according to the staining degree (highly intense: +3 , moderately intense: +2 , slightly intense: +1 and no reaction: 0).

\section{Results}

Histological results for the kidney tissue: Histologically of mice kidneys in the controls groups and only Onosma nigricaule applied control group showed normal morphologic appearance of kidneys with presence of normal glomeruli, afferent arterioles, and tubule cells. Similarly, only malathion and Onosma nigricaule plant extract groups also exhibited normal tubular and glomerular structure (Figure 1).

Immunohistochemical results: Microscopic examination revealed that specifically catalase and MnSOD immunohistochemical reaction was observed on all groups. CAT immunohistochemical reactivity was observed on the renal cortex. Some differences were observed on the CAT immunoreactivity in the cortex of all groups according to areas. It was remarkable that the immunoreactivity inside of the cortex was more intense compared to the medulla.

While an highly intense immunoreactivity $(+3)$ was observed on tubulus proximalis of mice in the control, maize oil group, normal saline and Onosma nigricaule groups, a slightly intense immunoreactivity (+1) was encountered in the malathion group, and a moderately intense immunoreactivity $(+2)$ was encountered in the Onosma nigricaule+malathion group (Figure 2). No CAT immunoreactivity (0) was observed in glomerulus, vascular endothelium, and tubulus distalis of renal tissues of all groups examined.

A highly intense cytoplasmic Mn-SOD immunoreactivity $(+3)$ was determined in renal medulla of mice in the control and Onosma nigricaule groups. A moderately intense immunoreactivity $(+2)$ was determined
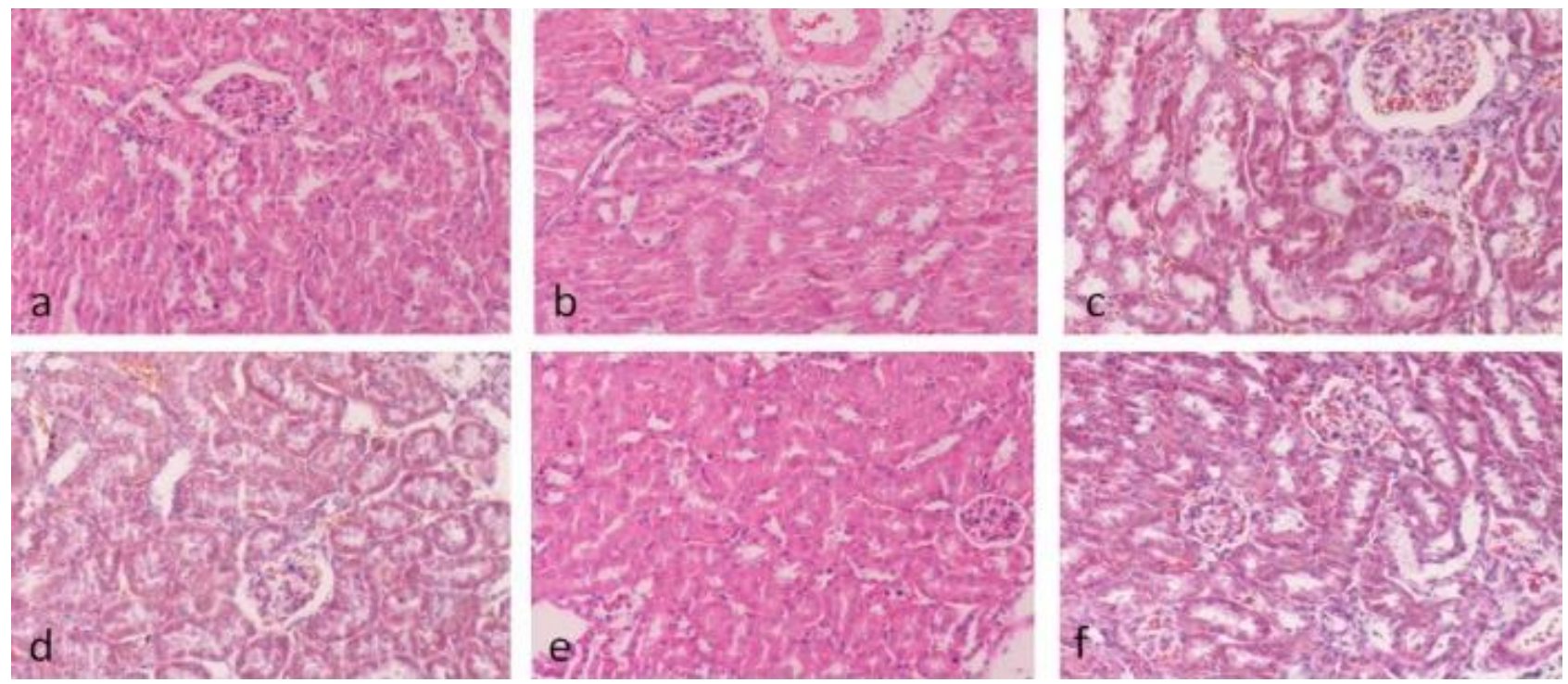

Figure 1. a) Control group (H\&E). b) Maize oil group (H\&E). c) Normal saline group (Triple staining). d) Onosma nigricaule group (Triple staining). e) Malathion group (H\&E). f) Onosma nigricaule+malathion group (Triple staining). Bar: $100 \mu \mathrm{m}$.

Şekil 1. a) Kontrol grubu (H\&E). b) Misır yağı grubu (H\&E). c) Serum fizyolojik grup (Triple boyamas1). d) Onosma nigricaule grubu (Triple boyamas1). e) Malathion grubu (H\&E). f) Onosma nigricaule + malathion uygulanan grup (Triple boyamas1). Bar: $100 \mu \mathrm{m}$. 

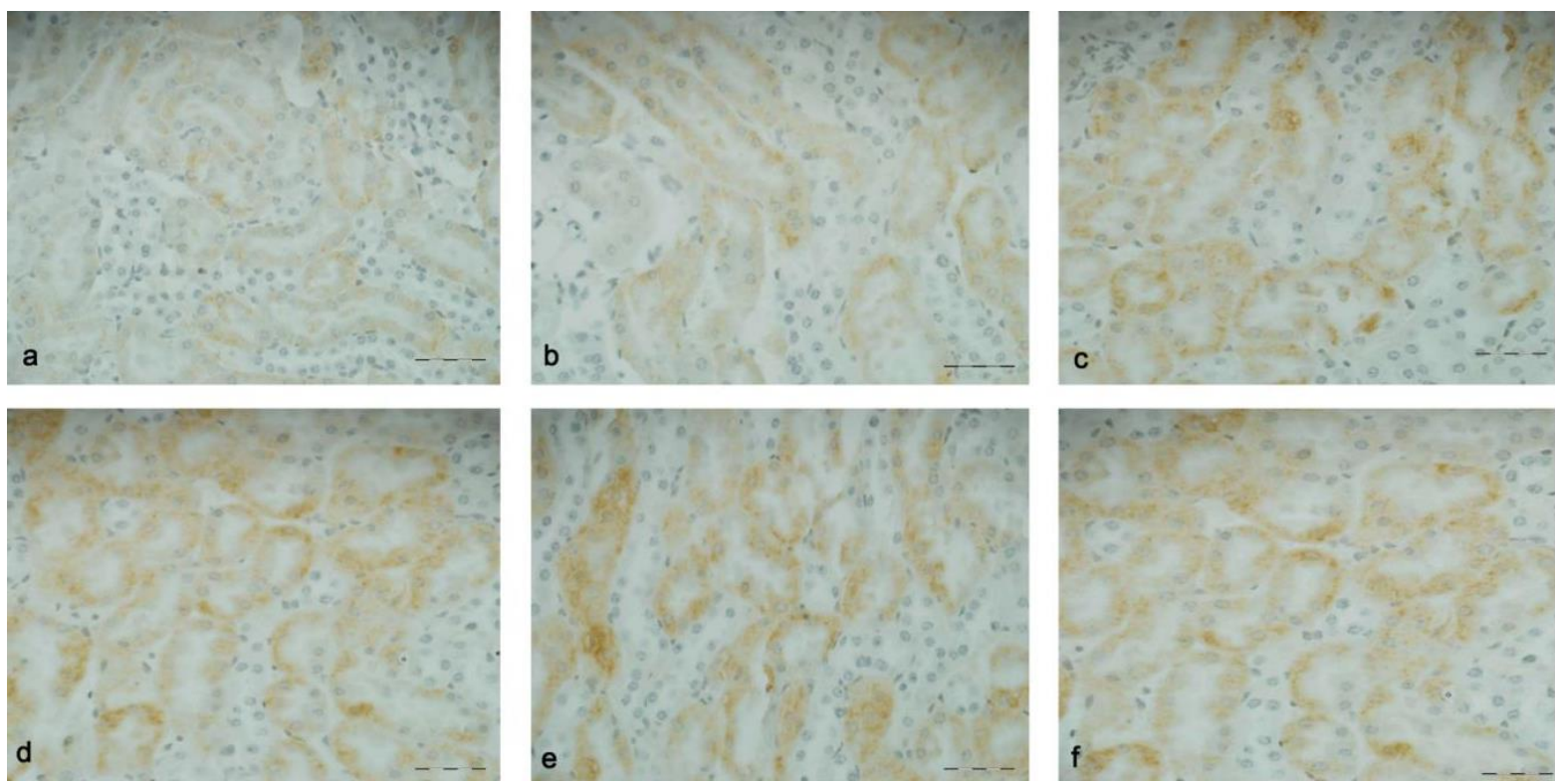

Figure 2. a) Renal section of the malathion group. Slightly intense CAT immunoreactivity in the tubulus proximalis. b) Renal section of the Onosma nigricaule+malathion group. Moderate intense CAT immunoreactivity in the tubulus proximalis. c) Renal section of the control group. Highly intense CAT immunoreactivity in the tubulus proximalis. d) Renal section of the maize oil group. Highly intense CAT immunoreactivity in the tubulus proximalis. e) Renal section of the normal saline group. Highly intense CAT immunoreactivity in the tubulus proximalis. f) Renal section of the Onosma nigricaule group. Highly intense CAT immunoreactivity in the tubulus proximalis. Bar:50 $\mu \mathrm{m}$.

Şekil 2. a) Malathion grubu böbrek kesiti. Tubulus proksimaliste hafif yoğunlukta CAT immunoreaktivitesi. b) Onosma nigricaule+malathion grubu böbrek kesiti. Tubulus proksimaliste orta yoğunlukta CAT immunoreaktivitesi. c) Kontrol grubu böbrek kesiti. Tubulus proksimaliste yüksek yoğunlukta CAT immunoreaktivitesi. d) Mısır yağı grubu böbrek kesiti. Tubulus proksimaliste yüksek yoğunlukta CAT immunoreaktivitesi. e) Serum fizyolojik grubu böbrek kesiti. Tubulus proksimaliste yüksek yoğunlukta CAT immunoreaktivitesi. f) Onosma nigricaule grubu böbrek kesiti. Tubulus proksimaliste yüksek yoğunlukta CAT immunoreaktivitesi. Bar:50 $\mu \mathrm{m}$.
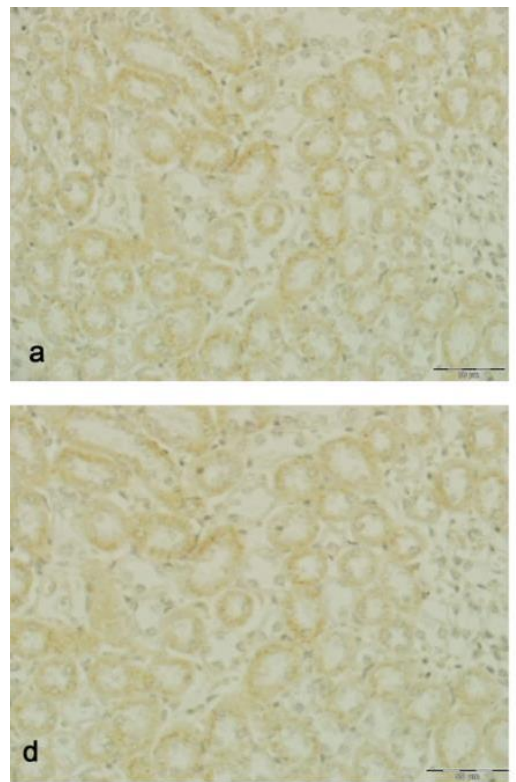
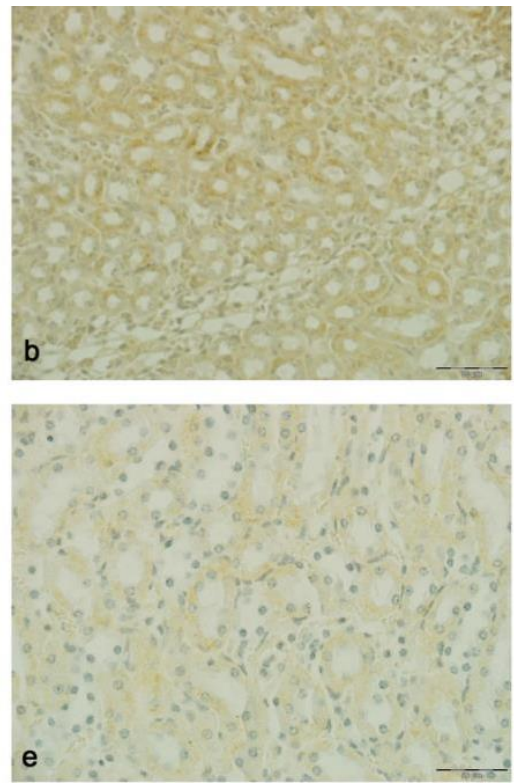
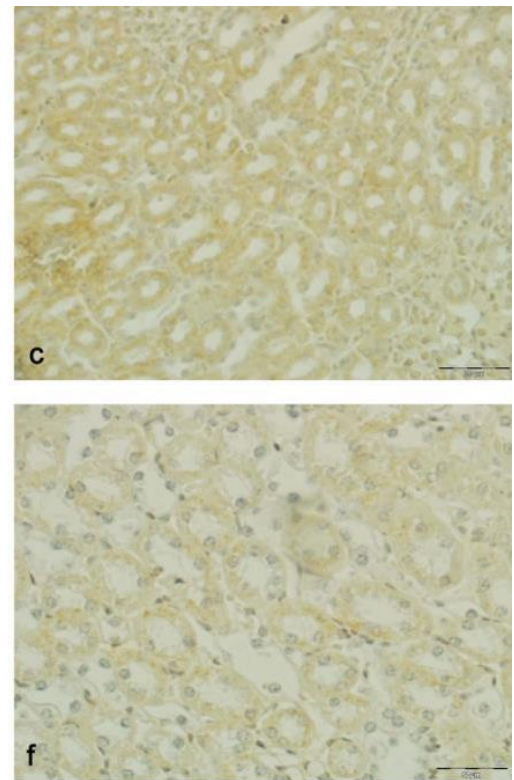

Figure 3. a) Renal section of the normal saline group. Moderate intense Mn-SOD immunoreactivity in the medulla. b) Renal section of the control group. Highly intense Mn-SOD immunoreactivity in the medulla. c) Renal section of the Onosma nigricaule group. Highly intense Mn-SOD immunoreactivity in the medulla. d) Renal section of the maize oil group. Moderate intense Mn-SOD immunoreactivity in the medulla. e) Renal section of the malathion group. Slightly intense Mn-SOD immunoreactivity in the medulla. f) Renal section of the Onosma nigricaule+malathion group. Moderate intense Mn-SOD immunoreactivity in the medulla. Bar:50 $\mu$ m. Şekil 3. a) Serum fizyolojik grubu böbrek kesiti. Medullada orta yoğunlukta Mn-SOD immunoreaktivitesi. b) Kontrol grubu böbrek kesiti. Medullada yüksek yoğunlukta Mn-SOD immunoreaktivitesi. c) Onosma nigricaule grubu böbrek kesiti. Medullada yüksek yoğunlukta Mn-SOD immunoreaktivitesi. d) Misır yağı grubu böbrek kesiti. Medullada orta yoğunlukta Mn-SOD immunoreaktivitesitesi. e) Malathion grubu böbrek kesiti. Medullada hafif yoğunlukta Mn-SOD immunoreaktivitesi. f) Onosma nigricaule+malathion grubu böbrek kesiti. Medullada orta yoğunlukta Mn-SOD immunoreaktivitesi. Bar:50 $\mu \mathrm{m}$. 
in the maize oil, normal saline and Onosma nigricaule+ malathion groups. On the other hand, a slightly intense Mn-SOD immunoreactivity (+1) was determined in renal medulla of mice in the malathion group (Figure 3).

\section{Discussion and Conclusion}

This study examined the changes caused by the plant extract, which is obtained from Onosma nigricaule (Boraginaceae) due to the oxidation parameters caused by malathion in mice on the renal tissue, as well as its effects on the catalase (CAT) and superoxide dismutase-2 (MnSOD), which are among antioxidant enzymes in the renal tissue, demonstration of immunohistochemically.

In biological systems, the free radical formation might occur during normal metabolic activities and also due to diet, environmental effects, drugs and other factors. Free radicals might cause various disorders and stimulate the formation of reactive oxygen types when they exceed the antioxidant defense capacity in the body $(7,10,14)$. This determined a strong CAT immunoreactivity in renal cortex of other groups, except for the malathion and Onosma nigricaule+malathion group. While an intense immunoreactivity was present in tubulus proximalis of mice in the control group, maize oil group, normal saline group and Onosma nigricaule group, a moderately intense immunoreactivity was present in the Onosma nigricaule+malathion group and a slightly intense immunoreactivity was determined in the malathion group. Similarly, while CAT immunoreactivity was observed on the tubulus epithelium of internal renal cortex and external renal cortex; there was no staining on the medulla in other studies $(2,13,20)$. In our study, the CAT enzyme activity decreased in the malathion group, compared to other groups. This decrease on the CAT level could be associated with the decrease of the CAT mRNA expression by the malathion (25). On the other hand, Onosma nigricaule caused an increase on the CAT immunoreactivity in the renal tissue. This condition makes us think that it might be associated with the antioxidant effect of Onosma nigricaule.

It is the enzyme system that is primarily effective in the defense system against free radicals in the cells. CAT and SOD enzymes are the compounds that prevent the accumulation of free radicals and the onset of lipid peroxidation. While SOD catalyzes the transformation of superoxide into the hydrogen peroxide, CAT takes charge in reactions that suspend hydrogen peroxide, which are formed by SOD, from cells (12). This decrease in the enzyme activity is associated with the increase in the amount of free radicals, which destroy the integrity and function of cellular membrane (7). Mn-SOD takes charge in the regulation of the cellular concentration of $\mathrm{O}_{2}$, which is a product of the cellular metabolism and a highly reactive oxidant, and its protection against the oxidative cellular injury (21). In the study, while the cytoplasmic Mn-SOD immunoreactivity was determined with a weak intensity in the renal medulla of mice in the malathion group, moderately intense immunoreactivity was determined in the maize oil, normal saline and Onosma nigricaule+malathion groups, and a slightly intense $\mathrm{Mn}$ SOD immunoreactivity was determined in the malathion group. In the study conducted by Nirmale et al. (22) on mice, they determined a low rate of Mn-SOD immunoreactivity in the medulla, which shows a parallelism with our study.

Malathion transforms into breakdown products by reaching the liver through blood circulation and being metabolized by multi-function oxidase, which is located in the smooth endoplasmic reticulum on a membrane. Various studies demonstrate that breakdown products might cause the inhibition of some enzymes $(9,15)$. Renal tissue has antioxidants that prevent the damages caused by excessive oxygen metabolites. These antioxidants activate through separating the peroxides and catching the free radicals. SOD and CAT protect the cells against the toxic effect of superoxide radicals $(6,30)$. The decrease that was determined in CAT and Mn-SOD in the renal tissue of the group applied with malathion compared to the control group made us conclude that malathion and its breakdown products have an inhibiting effect on the enzyme activity. On the other hand, the findings of this study support the fact that Onosma nigricaule has a protective role against the inhibiting effect of malathion.

As a consequence, this conducted on mice revealed that malathion, which is commonly used as insecticide in Turkey, affects the catalase and Mn-SOD activities in kidneys of mice. Also Onosma nigricaule decreases the negative effects showed by malathion against these antioxidants that are oscillated from the kidney. Thus, further studies are required in order to precisely explain the antioxidant effects of Onosma nigricaule at molecular level.

\section{References}

1. Ami BH, Haim SA (1992): Direct effect of phosphamidon on isolated working rat heart electrical and mechanical function. Toxicol Appl Pharm, 110, 429-439.

2. Bingöl SA, Kocamış H (2010): The gene expression by RT$P C R$ and immunohistochemical expression pattern of catalase in the kidney tissue of both health and diabetic mice. J Fac Vet Med, 16, 825-834.

3. Buratti FM, D'Aniello A, Volpe MT, et al. (2005): Malathion bioactivation in the human liver: The contribution of different cytochrome p450 isoforms. Drug Metab Dispos 33, 295-302.

4. Cadırcı E, Suleyman H, Aksoy H, et al. (2007): Effects of Onosma armeniacum root extract on ethanol-induced oxidative stres in stomach tissue of mice. Chem Biol Interact, 170, 40-48. 
5. Erdăg D (2012): The effects of allium czelghauricum (liliaceae), lathyrus karsianus (fabaceae) and onosma nigricaule (boraginaceae) extracts on oxidation parameters in malathion treated mice. Health Science Institute, Kafkas University, PhD thesis.

6. Fadillioglu E, Erdogan H, Sogut S, et al. (2003): Protective effects of erdosteine against doxorubicininduced cardiomyopathy in mice. J Appl Toxicol, 23, 71-74.

7. Freeman BA, Crapo JD (1982): Biology of disease: Free radicals and tissue injury. Lab Inves, 47, 412-426.

8. Fridovich I (1983): Superoxide radical: An endogenous toxicant. Ann Rev Pharm Toxicol, 23, 239-257.

9. Gerdy GF, Rose HA, Starey NH (1987): Effect of lenght of exposure to malathion on xenobiotic biotransformation in male rat liver. Toxicol Lett, 38, 193-19.

10. Glusczak 1, Miron DDS, Moraes BS, et al. (2007): Acute effects of glyphosate herbicide on metabolic and enzymatic parameters of silver Catfish (Rhamdia Quelen). Comp Biochem Physiol Part C, 146, 519-524.

11. Guest JA, Copley MP, Hormenic KL (1991): Carsinogenic effects of pesticides. Pathol Pharmacol, 73, 387-390.

12. Halliwell B, Gutteridge JMC (1989): Free radicals in biology and medicine. Clarendon Press. Oxford. UK. Last Edition 2007, p: 95.

13. Johkura K, Usuda N, Liang Y, et al. (1998): Immunohistochemical localization of peroxisomal enzymes in developing rat kidney tissues. J Histochem Cytochem, 46, 1161-1173.

14. Keramati V, Jamili S, Ramin M (2010): Effect of diazinon on catalase antioxidant enzyme activity in liver tissue of Rutilus rutilus. Jour Fisher Aqua Sci, 5, 368-367.

15. Kettarman AJ, Pond SM, Becker CE (1987): The effect of differantial induction of cytochrome P-450 carboxylesterase and glutathion $S$-transferase activities on malathion toxicity in mice. Toxicol Appl Pharmacol, 87, 389-392.

16. Lemos P, Medeiros RS, Zanuncio JC, et al. (2005): Effect of sublethal concentrations of permetherin on ovary activation in the predator. Braz J Biol, 65, 287-290.

17. Luna LG (1968): Manual of Histologic Staining Methods of Armed Forces Institute of Pathology. Third ed. Mc GrawHill Book Comp, London.

18. Mates JM, Sanchez-Jimenez F (1999): Antioxidant enzymes and their implications in pathophysiologic processes. Front Biosci, 15, 339-345.

19. McEven FL, Stephenson GL (1989): The use and significiance of pesticides in the environment. John Wiley \& Sons Pub, New York, p:538.
20. Morikawa S, Harada T (1969): Immunohistochemical localization of catalase in mammalian tissues. J Histochem Cytochem, 17, 30-35.

21. Mukhopadhyay S, Das SK, Mukherjee S (2004): Expression of mn-superoxide dismutase gene in nontumorigenic and tumorigenic human mammary epithelial cells. J Biomed Biotech, 4, 195-202.

22. Nirmala P, Akira M, Sloane S, et al. (2011): Generation and characterization of a novel kidney-specific manganese superoxide dismutase knockout Mice. Free Radical Biol Med, 51, 406-416.

23. Pant N, Srivastava SP (2003): Testicular and spermatotoxic effects of Quinalphos in mice. J Appl Toxicol, 23, 271-274.

24. Peterson SV, Enghild JJ (2005): Extracellular superoxide dismutase: Structural and functional considerations of a protein shaped by two different disulfide bridge patterns. Biomed Pharmacother, 59, 175-182.

25. Sibilia V, Rindi G, Pagani F, et al. (2003): Ghrelin protects against ethanol-induced gastric ulcers in mice: studies on the mechanisms of action. Endocrinol, 144, 353359.

26. Tosun A, Akkol EK, Bahadir O, et al. (2008): Evaluation of antiinflammatory and antinociceptive activities of some Onosma L. species growing in Turkey. J Ethnopharmacol, 120, 378-831.

27. Tru LD (1990): Principles of Immunohistochemistry. True L.D. Atlas of Diagnostic Immunohistopathology. Newyork Press, USA, p: 1-31.

28. Valko M, Rhodes CJ, Moncol J, et al. (2006): Free radicals, metals and antioxidants in oxidative stres-induced cancer. Chem Bioll Interac, 160, 1-40.

29. Weizman Z, Sofer S (1992): Acute pancreatitis in children with anticholinesterase insecticide intoxication. Pediatr, $\mathbf{9 0}$, 204-206.

30. Yilmaz HR, Uz E, Yücel N, et al. (2004): Protective effect of caffeic ccid phenethyl ester (CAPE) on lipid peroxidation and antioxidant enzymes in diabetic rat liver. $\mathrm{J}$ Biochem Mol Toxicol, 18, 234-238.

Geliş tarihi:04.12.2015/Kabul tarihi: 22.04.2016

Adress for correspondence:

Yrd.Doç.Dr. Buket BAKIR

Namık Kemal Üniversitesi, Veteriner Fakültesi

Histoloji ve Embriyoloji $A B D$

Tekirdăg, Türkiye.

e-mail:buhal@hotmail.com 